\title{
Reclaimed Land in Relation to Land Acquisition for Development in The Public Interest (Law Number 2 of 2012)
}

\author{
Sri Herowanti Susilo \\ \{sri.herowanti@yahoo.com\} \\ Universitas 17 Agustus 1945 Jakarta, Jakarta, Indonesia
}

\begin{abstract}
This research reveals the relationship between coastal reclamation and national land law especially in Jakarta Provincial Government; whether or not the need to re-arrange the provisions of coastal reclamation in a generally accepted provision that is intersectoral and integrated in nature; the type of land rights granted by the competent authority to the land reclaimed by the beach. The research was carried out through field research as a primary data source, supported by library research which included existing coastal reclamation provisions and several other supporting literature as secondary data sources, with qualitative methods. Reclamation can be classified as land acquisition activities based on the Basic Agrarian Law. The legal basis for reclamation is contained in regulations that vary from region to region. Reclamation is a multidimensional activity, because reclamation is not only related to land issues but also relates to issues of forestry, the environment, maritime affairs including fishermen and urban population settlements. Reclamation is an efficient means of land acquisition, especially in the face of population growth and land issues in urban areas.
\end{abstract}

Keywords: Reclaimed Land, Acquisition Land, Development in the Public Interest, Jakarta Provincial Government.

\section{Introduction}

The Provincial Government of DKI Jakarta Province has carried out a restructuring of the existing coastal plain by conducting revitalization / reclamation. As for what is meant by reclamation is landfill activity with sea drying in the sea waters of Jakarta[1]. This reclamation in the waters of North Jakarta is a Regional Government plan that aims to expand urban areas due to rapid population growth and also to meet the needs of development carried out in Jakarta.

To implement this idea, Presidential Regulation No. 54 of 2008 in lieu of Presidential Decree No. 52 of 1995 concerning the Reclamation of the North Coast of Jakarta which gave authority and responsibility to the Governor of the Head of the Special Capital Region of Jakarta to carry out the Reclamation of the Jakarta North Coast Region.

According to his understanding in language, reclamation comes from English vocabulary, to reclaim which means to repair something that is broken. Specifically in the English-Indonesian 
Dictionary published by PT. Gramedia mentioned the meaning of reclaim as making land (from the sea). Still in the same dictionary, the meaning of the word reclamation is translated as work acquire land. Not many experts have defined or provided an understan ding of coastal reclamation. Coastal reclamation activities are technological efforts by humans to transform a natural environment into an artificial environment, a typology of es tuary ecosystems, mangroves and coral reefs into a landform[2]. Reclamation is an activity carried out by a person in the context of increasing the benefits of land resources from an environmental and socio-economic point of view by irrig ation, drainage or drainage (Law No. 27 of 2007)[3]. Another definition of reclamation is a job / business utilizing areas or land that are relatively useless or still empty and watery to be us eful by means of drying. For example in coastal areas, s wampy areas, offshore / in the sea, in the middle of a wide river, or in a lake. Basically, reclamation is an activity to change coastal waters into land. Reclamation is intended to change the low land surface (usually affected by standing water) to be higher (usually not affected by standing water)[4]

By definition, the main purpose of reclamation is to make watery areas that are damaged or useless become better and more useful. The new area, us ually used for residential areas, industry, businessand shopping, agriculture, and tourist attractions. In urban planning, coastal reclamation is one of the steps to expand the city [5]. Reclamation is practiced by countries or big cities whose growth rates and land needs are increasing so rapidly but are constrained by the increasingly narrow land area (limited land). Under these conditions, the expansion of the city towards the mainland was no longer possible, sonew facilities were renewed. Reclamation methods provide benefits and can help the state / city in the context of providing land for various purposes (city expansion), structuring coastal areas, developing marine tourism, etc. Reclamation of water areas is an effort to form a new land area both in the coastal area or in the middle of the ocean. The main purpose of this reclamation is to turn a damaged or untapped watery area into a new area that is better and useful for various economic needs as well as for other strategic purposes. The new land area can be utilized for residential, industrial, bu siness and shopping areas, airports, urban areas, agriculture, alternative transportation routes, coastal freshwater reservoirs, integrated waste and environmental management areas, and as embankments protecting old land from abrasion threats and to become an abrasion threat an integrated tourist area.

\section{Purpose of Reclamation}

This reclamation activity is usually carried out by an authority (state, big city, area manager) which has a high growth rate and land needs are increasing rapidly, but is experiencing constraints or limited availability of space and land to support the existing growth rate, so it is neces sary to develop an area new land. In the context of regional development, the reclamation of this coastal area is expected to be able to increase the overall carrying capacity and environmental support capacity of the region. Reclamation is carried out in the context of increasing the benefits of land resources in terms of environmental and socio-economic perspectives by irrigation, drainage or drainage (Law 27/2007)[6]. This generally occurs due to the high level of human population, especially in the coastal area, so that solutions need to be sought. The purpose of reclamation is also to improve areas or areas that are not used or are not useful to be areas that can be used for various human needs including agricultural land, housing , a place of recreation and industry [7]. Meanwhile, according to Max Wagiu 2011. The objectives of the reclamation program are: 
a. To regain land lost due to ocean waves

b. To acquire new land in the area in front of the coastline to erect a building that will function as a shoreline protection fort

c. For economic reasons, construction or to erect building construction on a larger scale. Reclamation that is separated from the mainland.[8]

\section{Benefits of Reclamation}

Coastal reclamation as an alternative to meeting the needs of urban land becomes absolute because of the increasingly narrow land area. The needs and benefits of reclamation can be seen from as pects of land use, coastal management and economic as pects. The spatial layout of a certain area sometimes needs to be reclaimed in order to be empowered and efficient. For beaches oriented to ports, industries, touris mor settlements where shallow coastal waters are required to be reclaimed to be utilized. Especially if in the port area, reclamation is an absolute neces sity for the development of port facilities, ship berths, container ports, warehousing and so on. In its development the export-import port is now a very wide area and the development of the industry because factories, modes of transportation, warehousing which have an export-import share prefer the place at the port location because it is very economical and capable of cutting transportation costs. The economic aspect is the need for land for settlements, the increasingly expensive land and the depletion of environmental carrying capacity on land makes reclamation an option for developed countries or metropolitan cities in expanding their land to meet the needs for settlements. Another function is to reduce the density that builds up in cities and to create areas that are free from evictions because they are in areas that havebeen provided by the government.

\section{Legal Basis of Reclamation in Jakarta Provincial Government}

In carrying out land acquisition for development purposes, it should always refer to the provisions of the 1945 Constitution Article 33 paragraph (3) of the 1945 Constitution states that "Earth, water and natural resources contained therein are controlled by the State and used for the greatest prosperity of the people". This understanding is controlled by further elaborating in Article 2 paragraph (2) of the UUPA No. 5/1960 (Basic Agrarian Law No. 5 of 1960 concerning Basic Rules of Agrarian Principle), namely: The state is given authority among other things to regulate and administer the designation, supply, use and maintenance of water and space earth. Included in this authority is the State authorized to carry out land acquisition for the implementation of development in the public interest.

Jakarta's North Coast Reclamation, the area along the coast of about 32-km is a gateway from the direction of the sea, with a variety of community activities and development that is very diverse, including vital objects in the area. Referring to Law 26/2007 on Spatial Planning (Article 10 Paragraph 1) which stipulates that each province is authorized to determine the Provincial Strategic Area, then based on the 2011-2030 DKI Jakarta Provincial RTRW, the Pantura (North Coast) of Jakarta is determined as the Provincial Strategic A rea. This is in line with Law 32/2004 on Regional Government and Law 29/2007 on Provincial Government of the Special Capital 
Region of Jakarta as the Capital of the Unitary State of the Republic of Indonesia (Article 26 Paragraph 4) which regulates the establishment and implementation of policies in the spatial, natural res ource and environment, population and settlement control, transportation, industry, trade and tourism, as the authority of the DKI Jakarta Provincial Government.

The North Coast Region (Pantura) was originally categorized as the Mainstay Area, which is a region that has strategic value from the economic and development point of view of the city, based on Presidential Decree 17/1994. Efforts to realize the function of the Jakarta North Co ast Region as a Mainstay Area, can be done through reclamation of the north coast as well as arranging space the existing coastal land in a directed and integrated manner, is a nomenclature of the enactment of Presidential Decree 52/1995 concerning the Reclamation of the North Coast of Jakarta.

Following up on the Central Government's policy on the development and structuring of the Jakarta Pantura Mainstay, the Provincial Government of DKI Jakarta issued Local Regulation 8/1995 concerning the Implementation of the Reclamation and Spatial Planning of the Jakarta Pantura Region.

In the latest developments, the Central Government is sued Presidential Decree No. 54/2008 on SpatialPlanning for the Regions of Jakarta, Bogor, Depok, Tangerang, Bekasi, Puncak, Cianjur (Jabodetabekpunjur). This area coverage refers to PP 26/2008 which stipulates the Jabodetabekpunjur area as a national strategic area, which therefore requires spatial planning, spatial use and integrated spatial usecontrol. This determination is related to the direction of the national strategic area as an ecoregion area.

With Law 26/2007 concerning Spatial Planning, PP 26/2008 concerning National Spatial Planning, PP 15/2010 concerning Spatial Planning and Presidential Regulation 54/2008 concerning Spatial Planning for Jabodetabekpunjur Region, then Presidential Decree 52/1995 concerning the Reclamation of North Jakarta Beach, especially those related to spatial planning are declared no longer valid. This has an effect on regulations at the re gional level, particularly those related to the arrangement of the Jakarta Pantura area, namely the Provincial Regulation of DKI Jakarta Province 8/1995 concerning the Implementation of the Reclamation and Spatial Planning of the Jakarta Pantura Region.

Basically Perpres 54/2008 still opens opportunities for development through reclamation, which is integrated with the revitalization area on its land. This is different from Keppres 52/1995 where reclamation can be done by extending land. Meanwhile, Presid ential Regulation 54/2008 regulates reclamation to be carried out by forming is lands, where there are lateral canals \pm 200 300 meters between land and reclamation islands, depending on the zoning.

Therefore, in its implementation a re-planning (spatialplanning) of the Jakarta Pantura area is needed, which includes land reclamation and land revitalization, in accordance with the mandate of Law 26/2007 Article 10 Paragraph 1, the provincial strategic area needs to be determined through a regional regulation and therefore the Jakarta Pantura Area as one of the provincial strategic areas as stipulated in the 2011-2030 DKI Jakarta Provincial Spatial Plan needs to be made a legalbas is in the form of the Pantura Strategic Area Spatial Plan as a revision of the DKI Jakarta Provincial Regulation 8/1995.

The high demand of the community for the development of the Jakarta Bay area has led to planning discussions between the Regional Government, the Central and Sectoral Governments as well as the community and the business world. In addition to being expected to be a reference for all planning in the Jakarta Pantura region, the Spatial Plan for the Jakarta Pantura region can also 
grow as a green city that integrates an eco-city and waterfront city that is independent towards resilience-city as the solution that is expected to be the most able to accommodate various interests environmental, economic and social as well as security for all stakeholders involved in Pantura Jakarta.

National spatial policy as regulated in Law 26/2007 concerning Spatial Planning and the directive of Law 27/2007 concerning Coastal Areas and Small Is lands, Law 29/2007 concerning Provincial Government of the Special Capital Region of Jakarta as the Capital of the Unitary State of the Republic of Indonesia, Law 32 / 2009 concerning the Protection and Management of the Environment and the Jakarta Bay of KLHS (Strategic Environmental Asses sment) Year 2010 and the mandate stipulated in the DKI Jakarta Provincial Regulation 1/2012 regarding the 2011-2030 DKI Jakarta RTRW is a reference in the stipulation of regulations in the framework of structuring the Pantura area Jakarta.

Article 12 of Presidential Decree 52 of 1995 states that "all costs required for the implementation of the Pantura Reclamation are carried out independently by the Governor of the Special Capital Region of Jakarta in collaboration with the private sector, the community and other legitimate sources according to the applicable laws and regulations. "According to Article 8 paragraph (2), the Implementing Body formed by the Governor of DKI Jakarta, in carrying out its duties, it is also" able to conduct business cooperation with other parties ", so long as" Implementing Pantura Reclamation and Business Cooperation does not reduce the authority and responsibility of the Governor The Head of DKI Jakarta as referred to in article 4, Article 8 paragraph 4. So the business cooperation constitutes the attributive authority of the Governor of DKI Jakarta, which is mandated to the Implementing Agency he has established.

Business cooperation in the framework of the implementation of the reclamation, both for the implementation of the reclamation or for the management of the reclaimed land according to Article 32 paragraph (1) and its Explanation, is carried out with the approval of the Jakarta DPRD, namely business cooperation between the Jakarta Pantura Reclamation Implementing Body with other parties, or BusinessEntities with other parties, if the assets of this Business Entity have not been separated from the as sets of the DKI Jakarta Government.

As in general, business contracts that have a public dimension, agreements or cooperation contracts in the framework of conducting reclamation are also limited by a number of provisions in Article 11 of Presidential Decree 52/1995 and article 34 of DKI Jakarta Regional Regulation No. 8 of 1995 requires, among other things, to pay attention to environmental interests, including the provisions regarding AMDAL. The regulations governing in detail the mechanism and material of business cooperation between the Governor of DKI Jakarta / BP Jakarta Reclamation Pantura published on. November 16, 2000 in the form of Decree of the Governor of DKI Jakarta No. 138 of 2000 concerning Procedures for Carrying Out North Jakarta Beach Reclamation.

\section{Legal Aspects}

Land in coas tal areas that are not encumbered with ownership rights, is controlled by the state and used according toits designation/ function for the prosperity of the people. The transfer of land status fromstate land to land held by rights that are not state land can be achieved through the process of releasing or releasing rights as regulated in the Basic Agrarian Law. 
Regulation that specifically regulates naturally aris ing land does not yet exist, however, PP No. $8 / 1953$ governing the exploitation of state lands, before there are new regulations.

The regulation regulates matters regarding immovable state property, including state lands. In this regulation it is stated that immovable and state-owned objects are under the authority of a Department, whose maintenance costs are incurred from the budget of the agency concerned. But, then it became unclear, if there were immovable objects belonging to the state, but there was no Department that budgeted their maintenance.

Other than PP No. 8/1953 above, it is also necessary to pay attention to Law No. 51/1960, concerning the prohibition to use land or the face of the earth for anyone who does not have a legal permit from the land authority. UU no. 1/1960 prohibits the illegal use of the face of the earth in any form, whether it is still in the form of periodic waterlogged soil or in the form of solid soil. With the Law No. 51/1960, the Regional Government is authorized to take necessary actio ns if there are violations of the law as mentioned above.

Land arises, whicheverstage it takes, there is usually vegetation. If someone cuts down trees but does not use the land immediately, that person can also be prosecuted as a violator of the law under Law No. 5/967 concerning Forestry Principles. If there is pollution or environmental damage, the claim can also be based on Law no. 4/1982.

Coastal reclamation that has been carried out in Jakarta so far has not caused problems in positive land law. Because the reclamation is not yet in the real sense, which is to hoard the coast to create new land. Part of the reclamation undertaken is to re-emerge land eroded by abrasion. So that the arising land remain s the same as the map of the area long before abrasion. And also some others are swampy areas or mangrove ecosystems which happen to be state land status.

The above will be different if the reclaimed is entirely sea. Therefore, land rights are only valid up to the coast s and limit. Therefore, the sea cannot be clung to land rights. Holders of the right to the sea up to the limit specified by the "UNConvention on the Law of the Sea" which Indonesia has ratified by Law No. 17 of 1985 is a country. So, the entire Indonesian sea area is authorized by the Department of Trans portation for shipping purposes.

The problem that can arise is how the land status that arises due to reclamation. As long as there are no definite leg al provisions, the problemcan be solved by following the existing positive land law provisions. If sorted out the stages of the emergence of new land are as follows:

First, in the form of sea which is controlled by the state.

Second, reclamation of permits granted by the government and reclamation permits can be granted after an AMDAL is carried out in accordance with Law No. 32 of 2009.

Third, new lands emerge which are of course controlled by the state, because the reclamation permit is merely for reclamation and not to control the reclaimed land.

After the new land is clear, then the community can request a right to the land from the government to use it in accordance with the designation determined by the government. Based on the principle of propriety, of course the reclamation party gets the first priority to apply for land rights.

Looking at the dynamics of national development at this time, it is not excessive if it is said that coastal reclamation will become a trend of urban area development in the future, at least for big cities in Java bordering the sea. Not only driven by the rate of population growth, but also 
because the business world will have more coastal reclamation in an effort to get strategic land, even with higher investment.

One day Java, due to population density and development activities, will resemble Singapore or Hong Kong which is forced to hoard the sea to increase land area. Therefore, it needs to be anticipated from now on by preparing legislation relevant to this trend.

It is time to formulate regulations at the level of the Law that regulates Lake / River reclamation / dredging activities as well as all related aspects and is sues, so that legal certainty can be given to such a large amount of work. Because, legalcertainty, in terms of this land law, is also an absolute prerequisite for the success of national development[9].

Coastal reclamation is closely related to land is sues. The question of land is closely related to the issue of justice. To avoid violating the sense of justice for the Indonesian people, coastal reclamation should be regulated within the framework of land regulations that are based on the Basic Agrarian Law, such as the Law on Land Procurement for Development in the Public Interest. Here are some is sues that need to be followed up:

a. Why is reclamation not included in the area of land law? Es pecially the legal system of land acquisition for development in the public interest. (Law No. 2 of 2012 concerning Land Procurement for Development in the Public Interest)

b. What if there was a new national law concerning reclamation under the Ministry of Maritime Affairs and Fisheries by accommodating all the interests of related agencies.

\section{Method}

In compiling this research, the author conducts normative juridical research in empirical field research with qualitative methods supported by library research. The author limits the rocess of collecting primary data is sues relating to land and reclamation processes carried out by the private sector. The research was conducted through field research as a primary data source supported by library research which included provisions on existing land and reclamation and several other supporting literature as secondary data sources. With qualitative methods. In conducting research in the field of science, there are two kinds of research methods, namely lbrary research and field research. The purpose of these two research methods is to search for as much material or data as possible in order to approach a truth in the context of primary data collection, the authors contact:

a. Jakara North Coast Reclamation Development Association,

b. Jakarta Provincial Development and Planning Consultant Team,

c. Related agencies in the ranks of Service and Bureau in the Jakarta Provinceal Government.

Field research is carried out to complete the required data so that it can be complement other supporting data. Whereas the secondary data here is obtained by conduction a library research on the legis lation including conducting research on other supporting literature. 


\section{Result and Discussion}

In terms of state control over the earth or land, it implies that the state holds the power to control and seek all resources agrarian power contained in the jurisdiction of Indonesia. Such an understanding, in line with the intention of the term to be controlled by the state, is aimed at the objects of control that are regulated in Article 33 paragraph(2) and (3) of the 1945 Constitution of the Republic of Indonesia, while the definition of rights according to Apeldoorn[10],, is a power (macht) which is organized by law which is based on morality. But power is not merely a right. Only power justified by law is the basis for the right to rule by the state.

In the state science literature the origin of state power is always as sociated with the theory of sovereignty (sovereigntyor souvereniteit), with the question of who is sovereign and who is the holder of power in a country. This discussion does not concern who holds power in the state, so that it is inappropriate to put forward theories of sovereignty as a source of state power. According to van Vollenhoven as quoted by Notonagoro, the state as the highest organization of a nation is given the power to regulate every thing and the state based on its position has the power to make legal regulations [11].

According to JJ. Rousseau, that state power as a body or organization of the people is sourced from the results of community agreements (social contract) which is essentially a form of unity that defends and protects the shared power, personal power and property of each individual[12]. In agreement the community, that which is released by each individual and handed over to his group (the community) is a portion of his power, not his authority. However, state power is not absolute power (postestas legibus omnibus soluta), because there are several legal provis ions that bind themselves such as the Natural Law and God's Law (leges nature et devinae) as well as the law common to all nations called leges imperil, imperil leges according Yudha B. Ardhiwis astra[13] is the state constitution which contains the provisions to whom the power is delegated and the limits of its implementation.

In harmony with the two theories or concepts above, theoretically the state power over natural resources comes from the people who are recognized as the rights of the nation. The state here, is seen as a territoriale publieke rechtsgemeenschap van overheid en onderdanen [14] which has the character as a legal society institution, so that it is given the power or authority to regulate, manage and maintain (supervise) the utilization of all potential natural resources (natural resources) that exist within its territory intensely.

Other theories about power, the state can also control people (individuals) in addition to natural resources or wealth (things). The two objects of state power, by Montesquieu, are dis tinguished by strictly separating the concepts of empire versus dominium[15]. Imperium is the concept of the rule over all individuals by the prince, while dominium is the concept of the rule over things by the individuals[16]. This concept is the forerunner to the differentiation of political and economic power or the differentiation of political and economic sovereignty. In fact, it has been institutionalized in juris prudence through the dis tinction between the realm of public law (political law) and private law (civil law) with objects that are separated fromeach other[17], although apart from the Montesquieu concept, both concerning people or individuals or objects or things, in a manner can theoretically become an object of power simultaneously. Regarding Montesquieu's opinion, Roscoe Pound[18] said that the things meant by Montesquieu were interpreted as objects 
(objects of wealth). The objects referred to by the Roscoe Pound can be divided into: objects that can be owned and objects that cannot be owned individually that he calls res extra commerdum.

In relation to the state's right to control natural resources[19], especially land, the relevant state power objects are wealth according to Montesquieu and objects (wealth objects) according to the Roscoe Pound because both are sources of the country's economy and points of prosperity people. In line with that, Bertrand Russel said that in a country, control of the economic field depends on and is determined by state law[20].

The Concept of Procurement of Land Rights for Public Interest. The term "Land Procurement" became famous after the is suance of Presidential Decree Number 55 of 1993 concerning Land Procurement for the Implementation of Development in the Public Interest. The term land acquisition is also used in Presidential Regulation No. 36/2005 and Presidential Regulation No. 65/2006 and in Law No. 2 of 2012. continued with Government Regulation (PP) No. 71 of 2012 concerning Implementation of Land Procurement for Development in the Public Interest, and Regulation of the Head of BPN No. 5 of 2012 concerning Technical Guidelines for Land Procurement for Development in the Public Interest.

The term land acquisition is a substitute for the term "land acquisition" used in Minister of Home Affairs Regulation No. 15/1975 which regulates the previous exemption of land rights. The term exemption of land rights in the Minister of Home Affairs Regulation which regulates the exemption of land rights before. The termland rights exemption in the Minister of Home Affairs Regulation received a negative response by the community and land law activists (agrarian law) in connection with the many problems that arise in its implementation, as well as intending to accommodate the aspirations of various groups in the community as a reaction to the negative impact of land acquisition occur.

Legal conceptions supporting development. Development has consequences, that the law must not be left behind by the development process that occurs within the community, including development. Sustainable development requires a conception of law that is always able to encourage and directdevelopment as a reflection of the goals of modern law. In the GBHN it is stated that the law must encourage the process of modernization. For developed countries, the concept becomes the initial concept of the Roscoe Pound whose orientation is based on juris prudence (common law system). The law referred to here is legis lation and jurisprudence in the atmosphere of the industrial community to the information society, i.e. that the law regulates technological development so that technology is not intended to destroy humans [21].

\section{Conclusions and Suggestions}

\section{Conclusions}

1. Coastal reclamation is an activity to expand the land surface and is closely related to land acquisition is sues. Thus the reclamation activities are included in the area of national land law.

2. Provisions governing coastal reclamation need to be reorganized so that these provisions are within the territory of the land legal systemso that they become an integral part of the provisions governing land acquisition sourced in the Basic Agrarian Law 
3. Coastal reclamation is a multidimensional activity. Reclamation is not only in contact with environmental problems. Directly or indirectly, reclamation can come into contact with forestry, marine and fis heries is sues. It can even be in contact with national borders as happened in Singapore.

4. Reclamation is not regulated in a generally accepted provision, but rather regulated in a different regulation from one another. Each reclamation area has its own reclamation provisions and implementing rules.

Suggestion:

1. Reclamation activities should be regulated in one generally accepted provision for reclamation activities carried out throughout Indonesia. With regard to special circumstances, the generally accepted provisions are implemented with implementing regulations as technical guidelines and implementation of reclamation activities that apply only to each region.

2. Because the impact of the reclamation activity is so extensive, it is recommended that the reclamation provisions strictly regulate the requirements for carrying out an environmental impact analysis that must be fulfilled by the reclamation implementer. In other words, the provisions contained in Law No. 32 of 2009 and its implementing regulations must be part of the reclamation provisions. Making an analysis of the environmental impact in the context of reclamation activities is very important to maintain the balance of the living environment structure of the coastal area and the location of the origin of the embankment material, so that the reclamation goal can be achieved without causing disasters for the surrounding population.

\section{References}

[1] PresidentialDecree No. 52 of year 1995 (Pasal 1, Ayat (1) regarding Reclamation of North Jakarta Coastal and Jakarta Province Regulation No. 8 of year 1995 regarding ... has been replace with Presidential Decree No. 54 of the Year 2008 regarding Tata Ruang Jabodetabek (Jakarta Bogor Depok Bekasi)

[2] Maskur, Typological of Estuaria Ekosystem, Mangrove and Terumbu Karang, Jakarta, 2008

[3] Statue No. 27 of the year 2007 regarding Pengelolaan Wilayah Pesisir dan Pulau-Pulau Kecil [4] Maskur, Wisnu Suharto, Tipologi Ekosistem Estuaria, Mangrove dan Terumbu Karang, Jakarta, 2008

[5] http//www.lautkita.org

[6] Undang-Undang No. 27 tahun 2007 tentang Pengelolaan Wilayah Pesisir dan Pulau-Pulau Kecil

[7] Ensiklopedi Nasional Indonesia, Jakarta, 1990

[8] Sumber:Japermana, 2013

[9] http//www.dephut.go.id/INFORMASI/RRI/STS, mangrove.HTM

[10] Sasino, Oetari, Pengantar Ilmu Hukum, Jakarta, Pradnya Paramita, 1985 hal. 22 
[11] Notonagoro, Politik Hukum dan Pembangunan Agraria di Indonesia, Jakarta, Bina Aksara, 1984, hal 99

[12] Wiratno R, Ahli-Ahli Pikir Besar Tentang Negara dan Hukum, Jakarta, PT Pembangunan, 1958, hal 176

[13] Yudha B. Ardhiwisastra, Imunitas Kedaulatan Negara di Forum Pengadilan Asing, Bandung, Alumni, 1999, hal 20

[14] Ronald Z. Titahelu, Penetapan Asas-Asas Hukum Umum Dalam Penggunaan Tanah Untuk Sebesar-besar Kemakmuran Rakyat, Disertasi, Surabaya, PPS-UNAIR, 1993, hal 141

[15] Jimly Asshiddiqie, Gagasan Kedaulatan Rakyat Dalam Konstitusi dan Pelaksanaannya di Kota, Jakarta, Ichtiar Baru Van Hoeve, 1994, hal 12

[16] Sugiharto, Umar Said, Hukum Pengadaan Tanah, Setara Press, Malang, 2015, hal 3

[17] Sugiharto, Umar Said, Hukum Pengadaan Tanah, Setara Press, Malang, 2015, hal 3

[18] Sugiharto, Umar Said, Hukum Pengadaan Tanah, Setara Press, Malang, 2015, hal 3

[19] Di Indonesia, terjemahan Resmi National Resources ialah Sumber Daya Alam, sedangkan untuk Human Resources ialah Sumber Daya Manusia

[20] Basir, Hasan, Kekuasaan Sebuah Analisis Sosial Baru, Jakarta, Yayas an Obor Indonesia, 1988, hal 89

[21] Kusuma Atmaja, Mochtar, Konsep-Konsep Hukum Dalam Pembangunan, Alumni, 2002, hal. v, vi 